\title{
Hepatic carcinosarcoma with rhabdomyosarcoma: A case report and review of literature
}

\author{
Gongbo Liang, Guangning Yan, Xuwen Lai, Huangwen Lai, Yunfeng Qian, Zhuocai Wang* \\ Department of Pathology, Liu Huaqiao Hospital, China
}

Received: July 16, 2020

Accepted: October 17, 2020

Online Published: December 25, 2020

DOI: $10.5430 /$ crep.v7n1p40

URL: https://doi.org/10.5430/crcp.v7n1p40

\begin{abstract}
Objective: To study the clinical and pathological manifestations in a case of hepatic carinosarcoma with rhabdomyosarcoma differentiation (HCSR).

Methods: A case of HCSR was clinically and pathologically evaluated by macroscopy, microscopy, immunohistochemistry (IHC) and electron microscopy, along with thorough review of related literatures.

Results: HCSR tends to occur in elder patients without gender skew. This disease initially presented as an epigastric illness, with elevated serum Alpha-fetoprotein (AFP) and a mass on the right liver discovered through radiography. The patient in this report carried both hepatic carcinoma and variously differentiated forms of sarcoma components, with identifiable rhabdomyosarcoma. Immunohistochemistry staining showed that the hepatic carcinosarcoma was positive for epithelial markers; the mesenchymatous component was diffuse-like positive for Vimentin and mosaic-like positive for SDHB, CD117; and the rhabdomyosarcoma was positive for the muscular markers, respectively. Transmission electron microscopy images showed the tumor had both epithelial and rhabdomyosarcoma ultra-microstructures.

Conclusion: HCSR are malignant tumor associated with poor prognosis, and is difficult to diagnose due to its unique and varied clinical manifestations. In this case study, we used a combination of methods including assessing histomorphology, immunohistochemistry, and ultra-microscope observations to further determine criteria for differential diagnosis.
\end{abstract}

Key Words: Hepatic carcinosarcoma, Rhabdomyosarcoma, Clinical pathology, Immunohistochemistry, Ultra-microstructure

\section{INTRODUCTION}

Carcinosarcoma refers to a tumor in which both epithelial and mesenchymal forms of malignant cells or tissue structure could be found. It is a very rare kind of disease with a high grade malignancy and a poor prognosis. Carcinosarcoma is more frequently found in lung, esophagus, uterus, and breast, and is rarely discovered in the liver. ${ }^{[1]}$ In most cases, the sarcoma component is in the fibrosarcoma form; and is much less likely to be in the rhabdomyosarcoma component form. Globally, the rhabdomyosarcoma component form has only been reported in four cases prior to this case study.
Our current case report documents a new case of liver carcinosarcoma with rhabdomyosarcoma, and we have provided analysis of both clinical characteristics and pathological manifestations of this disease by assessing tissue morphology, molecular phenotype, and ultrastructural characteristics.

\section{Case presentation}

\subsection{Clinical data}

A 57-year-old female patient suffered from repeated upper abdominal pain for half a year, with symptoms progressing during the most recent half a month. Physical examination:

*Correspondence: Zhuocai Wang; Email: zhuocaiwang0517@gmail.com; Address: Department of Pathology, Liu Huaqiao Hospital, China. 
In addition to the upper abdomen bulge, a soft mass was recorded in the right upper quadrant with nodular surface. Rebound pain was not found. Serology: HBsAg, $\mathrm{HBeAb}$, $\mathrm{HBcAb}(+)$, AFP and CEA were normal. Ultrasound: A mixed echoic nodule, about $67 \mathrm{~mm} \times 75 \mathrm{~mm}$, with clear boundaries and regular shape in S4 (segment IV of the liver) was imaged. CDFI: A peripheral blood flow signal, which was indistinguishable from the posterior wall of the gastric antrum was observed (see Figure 1). CT scan: a round lowdensity mass shadow on the left lateral liver lobe with poorly circumscribed boundary. The protrusion of the hepatic cap- sule was observed and the largest cross-section was about $98 \mathrm{~mm} \times 73 \mathrm{~mm}$. It displayed uneven density with patchy mass of slight hyper-density, nodular calcification and patchy shaped low-density areas. The margin between mass and partial gastric antrum was poorly circumscribed (see Figure 1). The patient received Hepatectomy, in which a spherical mass with a clear border on the left lateral liver lobe was resected and transported to the pathology department immediately. The longest diameter of the mass was almost $10 \mathrm{~cm}$. No definite adhesion between the capsule and the stomach wall was observed.
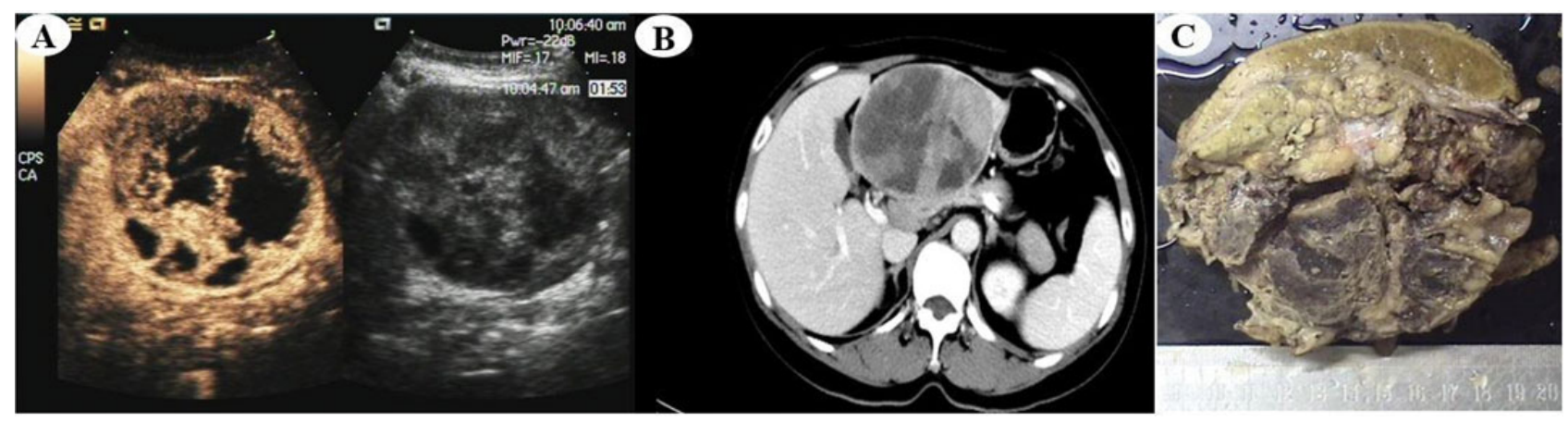

Figure 1. A) Ultrasound Images, B) Computerized tomography Images, and C) Gross Image of resected tissue

\subsection{Methods}

Specimens were fixed with $10 \%$ neutral formalin, embedded in paraffin and then were sectioned and stained with Hematoxylin \& Eosin (HE). Immunohistochemical (IHC) staining adopted EnVision two-step method, using primary antibodies of CK, Vimentin, HepPar-1, AFP, PDGFR- $\alpha$, P53, SDHB, Desmin, S-100, CD34, HMB45, Glypican3, Myogenin, MyoD1, Actin, Ki67, EMA, CK8, CK18, CD117, CD99, SMA, CgA, Dog-1, NSE, CD56, and CEA, which were purchased from Applied Biological Materials Inc., (Zhenjiang, Jiangsu Province, China). Both positive and negative controls were included in the IHC analysis. Positive criteria: Brown-yellow particles located in the membrane, cytoplasm and/or nucleus. Specimen for electron microscopy: Specimen volume was about $1 \mathrm{~mm} \times 1 \mathrm{~mm} \times$ $1 \mathrm{~mm}$. Glutaraldehyde-osmium tetroxide double fixation was performed and followed by epoxy resin embedding, ultrathin sectioning for 40nm-60nm, and electronic staining with saturated uranium acetate-lead dye solution. Observation was performed through the usage of Hitachi H-7650 transmission electron microscope.

\subsection{Results}

\subsubsection{Gross observation}

Gross examination of a gray-pink mass indicated that the overall size was about $13 \mathrm{~cm} \times 11 \mathrm{~cm} \times 6 \mathrm{~cm}$, with the solid and gray-red cut area as $13 \mathrm{~cm} \times 3 \mathrm{~cm} \times 2.5 \mathrm{~cm}$, the

Published by Sciedu Press gray-brown area as $11 \mathrm{~cm} \times 10 \mathrm{~cm} \times 4 \mathrm{~cm}$, and the cystic and gray-brown area as $9.5 \mathrm{~cm} \times 8 \mathrm{~cm} \times 4 \mathrm{~cm}$, respectively. The liver tissue boundary remained clear (see Figure 1).

\subsection{Histological observation}

The tumor was composed of both epithelial cells and spindle cells, and epithelial-mesenchymal transition was not observed in this case. Epithelial cells in this tissue were arranged in the form of strips or nests with oval or polygonal nucleus. The cytoplasm was rich with lightly or bright staining. The scattered multinucleated giant cells were frequently observed with active mitosis and pathological mitotic figures. Those sarcoma-like cells displayed various differentiation morphology. Short spindle cells were distributed uniformly with no obvious differentiation. The cells demonstrated a large nucleus-to-plasma ratio, strongly stained nuclei, thick nuclear membranes, and coarse granular chromatin. In moderately differentiated areas, long spindle-shaped cells arranged in bundles or braids with mitotic figures at 10-12 cells/10 HPF. In a well-differentiated tissue area, the cell was in the forms of oval or "tadpole-like" shape. Those cells were mononuclear or binuclear and the nucleus was large, round-shaped, center or deviated localized. The nucleolus was obvious and acidophilus. The cytoplasm was rich, acidophilus, with vacuoles observed near the nucleus. Multinuclear or megakaryocytic were scattered with mitotic 
figure about 5-7/10HPF and very active pathological mitotic figures (see Figure 2). In addition, we found a few oligoplasmatic, lightly stained, round nucleus or oval-shaped cells in astro-reticular myxoid matrix along with dilated thin-walled blood vessels and mini-focal matured bone and bone marrow tissue.
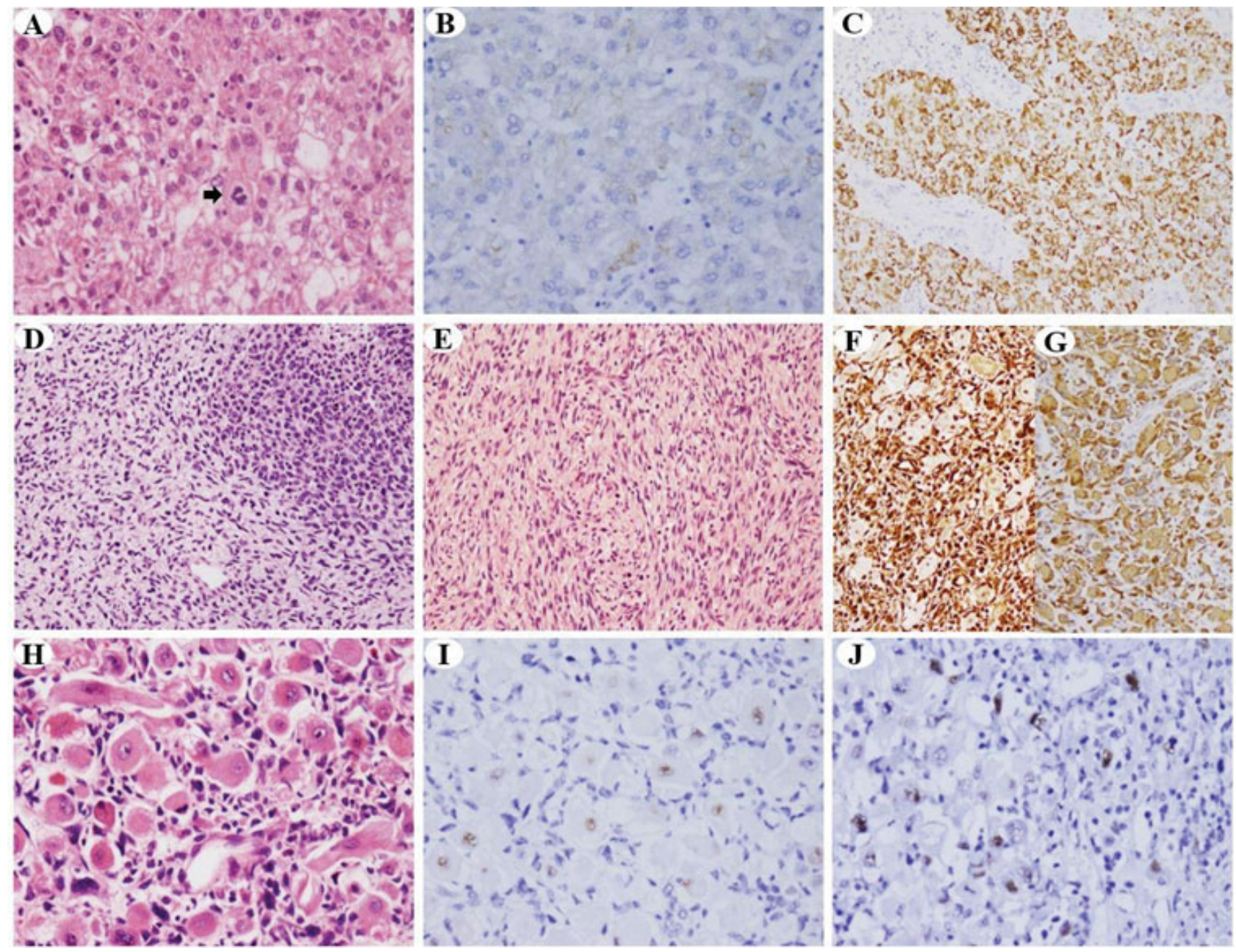

Figure 2. A) Epithelial cells were polygonal, arranged in the form of strips or nests, in which giant neoplastic cells were observed. Pathological mitotic figure (black arrow, HE 200X). The hepatic carcinoma was weakly positive for CK B) and diffuse positive for HepPar-1 C). (EnVision 200X). D) Poorly differentiated spindle cells. Uniformly dense short spindle shaped cells with strong nuclei staining and big nucleo-plasma ratio (HE 200X). E). Medium-differentiated spindle-shaped cells. Medium-density long spindle-shape cells arranged in bundles or braids (HE 200X). F) The sarcoma component was diffusely positive for Vimentin (EnVision 200X). G) The rhabdomyosarcoma component was positive for Desmin (EnVision 200X). H)-J) The rhabdomyosarcoma components (HE 400X), Myogenin I) and MyoD1 J) were positive at the nucleus (EnVision 400X).

\subsubsection{Ultramicrostructure study}

Some tumor cells had rich cytoplasm and irregular appearance, and were arranged in a disordered pattern. The size of nucleus varied along with increasing quantities and nucleuscytoplasm ratio. The increasing heterochromatin aggregated under the nuclear membrane. Some cells were round or spindle-shape and their nucleus were spindle shaped with irregular or abnormal nuclear edge. The nucleolus was easy to find, with increased heterochromatin, showing massive distribution. The cytoplasm was abundant, in which there were a large number of parallel thick or thin muscle filaments and Z-like substances. The form of hexagonal lattice-like structure could be found in the cross section (see Figure 3). 

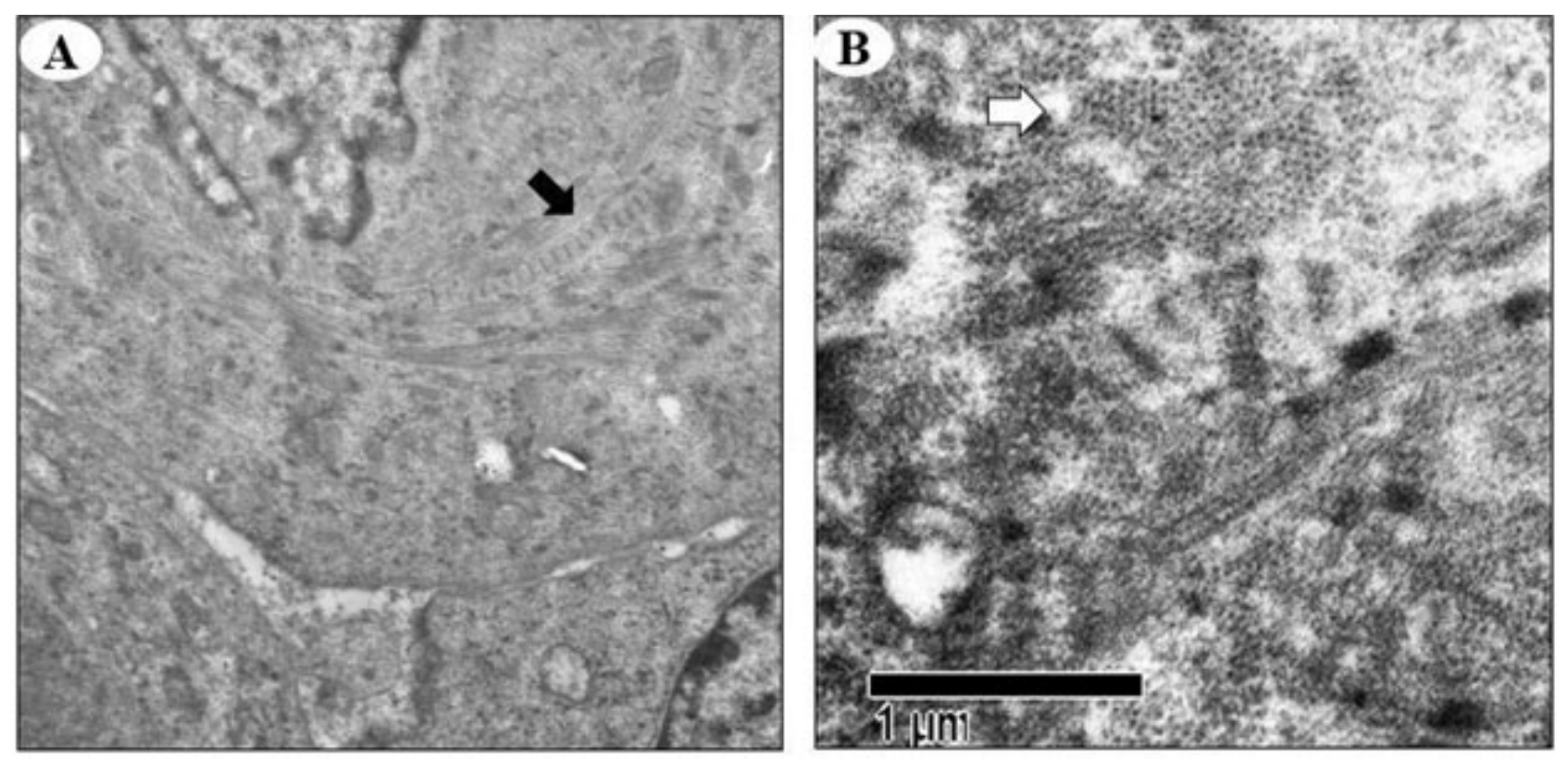

Figure 3. A) Z-like substance in tumor cells (A black arrow, 21700X); B) Hexagonal lattice-like structure in cross section (B white arrow, 65000X).

\subsubsection{Immunohistochemistry examination}

Immunohistochemistry staining was performed as described following Table 1.

in the method. The staining result was summarized as in the

Table 1. Immunohistochemical Staining Result

\begin{tabular}{|c|c|c|c|c|}
\hline \multirow{2}{*}{ IHC } & \multirow{2}{*}{ Epithelial cells } & \multicolumn{3}{|c|}{ Spindle shaped cells } \\
\hline & & Poorly differentiated & Moderately differentiated & Well differentiated \\
\hline$\overline{\mathrm{CK}^{\# 2}}$ & weak + & - & - & - \\
\hline Vimentin ${ }^{\# 2}$ & - & + & + & + \\
\hline HepPar- ${ }^{\# 2}$ & + & - & - & - \\
\hline Glypican-3 $3^{\# 3}$ & + & - & - & - \\
\hline CK18 ${ }^{\# 2}$ & + & - & - & - \\
\hline $\operatorname{Desmin}^{\# 2}$ & - & - & - & + \\
\hline Myogenin ${ }^{\# 1}$ & - & - & - & + \\
\hline MyoD1 $^{*}$ & - & - & - & + \\
\hline $\operatorname{Actin}^{\# 2}$ & - & - & - & + \\
\hline $\mathrm{CD} 117^{\# 3}$ & + & - & few* $^{*}$ & + \\
\hline $\mathrm{SDHB}^{\# 2}$ & + & - & - & + \\
\hline $\mathrm{Ki} 67^{\# 1}$ & $30 \%$ & $75 \%$ & $15 \%$ & $25 \%$ \\
\hline
\end{tabular}

Note. The brownish-yellow particles were positive for staining and located at:

${ }^{\# 1}$. Nucleus; ${ }^{\# 2}$. Cytoplasm; ${ }^{\# 3}$. cytoplasm / cell membrane; * positive tumor cells were less than $10 \%$

\section{Discussion}

\subsection{Clinical Features}

Hepatic carcinosarcoma with rhabdomyosarcoma, (HCSR), is a rare type of malignant tumor in liver. Up to date, only 4 cases have been reported (see Table 2). There is no gender difference observed in patients. The age range is from 52 to Published by Sciedu Press
70 years, and the mean age is 59.2 years old. Most of them have discomforts in the liver area or upper abdomen, and elevated AFP can be found usually. Most image examinations identify nodules in liver. We describe a prolonged survival case of HCSR in a 57-year-old female patient in this report. In this case, the patient suffered a single nodule in the left lobe of the liver, but with normal AFP. 
Table 2. Clinical Features of Five HCSR Cases

\begin{tabular}{|c|c|c|c|c|c|c|}
\hline Case & Age & $\begin{array}{l}\text { Clinical } \\
\text { Presentation }\end{array}$ & Gross & Light Microscope & $\begin{array}{l}\text { IHC and other } \\
\text { Examinations }\end{array}$ & Prognosis \\
\hline 1 & 70 & $\begin{array}{l}\text { Diarrhea, } \\
\text { abdominal pain } \\
\text { AFP } 3100 \text { ng/ml }\end{array}$ & $\begin{array}{l}4 \mathrm{~cm} \text { and } 2 \mathrm{~cm} \text { in } \\
\text { diameter tumors in } \\
\text { the right lobe of } \\
\text { the liver }\end{array}$ & $\begin{array}{l}\text { Hepatocellular } \\
\text { carcinoma with large } \\
\text { tumor cells rich in } \\
\text { eosinophilic cytoplasm }\end{array}$ & $\begin{array}{l}\text { PAS positive staining, } \\
\text { EM confirmed } \\
\text { Rhabdomyoblast }\end{array}$ & $\begin{array}{l}\text { death after two } \\
\text { months }\end{array}$ \\
\hline 2 & 52 & $\begin{array}{l}14 \text { yrs of hepatitis B } \\
\text { AFP } 9090 \mathrm{ng} / \mathrm{ml}\end{array}$ & $\begin{array}{l}19 \mathrm{~cm} \times 12 \mathrm{~cm} \times \\
11 \mathrm{~cm} \text { mass in the } \\
\text { right lobe of the } \\
\text { liver, multiple } \\
\text { satellite nodules }\end{array}$ & $\begin{array}{l}\text { Hepatocellular } \\
\text { carcinoma, } \\
\text { undifferentiated cells, } \\
\text { Rhabdomyoblast with } \\
\text { eosinophilic cytoplasm }\end{array}$ & $\begin{array}{l}\text { Liver cancer epithelial } \\
\text { marker and AFP } \\
\text { positive: Myogenic } \\
\text { marker positive for } \\
\text { rhabdomyoblast }\end{array}$ & $\begin{array}{l}\text { death after } \\
\text { three months }\end{array}$ \\
\hline 3 & 65 & $\begin{array}{l}\text { Right upper } \\
\text { abdominal pain } \\
\text { Weight loss }\end{array}$ & $\begin{array}{l}35 \mathrm{~cm} \times 15 \mathrm{~cm} \times \\
10 \mathrm{~cm} \text { mass in the } \\
\text { right lobe of the } \\
\text { liver. Extensive } \\
\text { necrosis and } \\
\text { bleeding }\end{array}$ & $\begin{array}{l}\text { Rhabdomyosarcoma } \\
\text { and hepatocellular } \\
\text { carcinoma, transition } \\
\text { area is visible }\end{array}$ & none & $\begin{array}{l}\text { death } 14 \text { days } \\
\text { after } \\
\text { admission }\end{array}$ \\
\hline 4 & 52 & $\begin{array}{l}\text { Upper abdominal } \\
\text { discomfort } \\
\text { HBsAg(+) } \\
\text { Increased } \\
\text { transaminase, AFP } \\
620 \mathrm{ng} / \mathrm{ml}\end{array}$ & $\begin{array}{l}6.5 \mathrm{~cm} \times 4.5 \mathrm{~cm} \\
\text { mass in the right } \\
\text { lobe of the liver } \\
\text { with partial } \\
\text { capsule }\end{array}$ & $\begin{array}{l}\text { Hepatocellular } \\
\text { carcinoma and } \\
\text { Rhabdomyoblast-like } \\
\text { differentiated area }\end{array}$ & $\begin{array}{l}\text { AFP positve, } \\
\text { Myogenic marker } \\
\text { positive for } \\
\text { rhabdomyoblast }\end{array}$ & $\begin{array}{l}\text { Spleen and } \\
\text { stomach } \\
\text { metastasis, } \\
\text { death more } \\
\text { than } 2 \text { months } \\
\text { after surgery }\end{array}$ \\
\hline $\begin{array}{l}\text { This } \\
\text { study } \\
\text { case }\end{array}$ & 57 & $\begin{array}{l}\text { Upper abdominal } \\
\text { pain for half a year } \\
\text { HBsAg, HBeAb, } \\
\text { HBcaB(+), normal } \\
\text { AFP and CEA }\end{array}$ & $\begin{array}{l}13 \mathrm{~cm} \times 11 \mathrm{~cm} \times \\
6 \mathrm{~cm} \text { mass in the } \\
\text { right lobe of the } \\
\text { liver. Mass } \\
\text { necrosis }\end{array}$ & $\begin{array}{l}\text { Stem cell carcinoma } \\
\text { with sarcoma, } \\
\text { Rhabdomyoblast } \\
\text { differentiation in } \\
\text { sarcoma }\end{array}$ & $\begin{array}{l}\text { Liver cancer epithelial } \\
\text { marker positive, } \\
\text { Myogenic marker } \\
\text { positive for } \\
\text { rhabdomyob last } \\
\text { confirmed by EM }\end{array}$ & $\begin{array}{l}\text { No recurrence } \\
\text { and metastasis } \\
\text { after } 12 \\
\text { months } \\
\text { follow-up }\end{array}$ \\
\hline
\end{tabular}

\subsection{Pathological features}

In most cases, solitary or multiple nodules lacking a capsule can be found in liver, indicating the high potential capability of invading adjacent organs. The diameter of the tumor can range from 2 to $35 \mathrm{~cm}$. The cut surface is grayish white and yellowish colored, and the texture varies depending on the proportion of hepatic cancer tissue and rhabdomyosarcoma as well as the presence of necrosis. HCSR is mainly composed of two components: a typical hepatocellular carcinoma and a rhabdomyosarcoma with possible transition between the two. In this case, a single nodule in the left lobe of the liver was found, and there is not obvious transition between carcinoma and sarcoma observed. The different components of sarcoma were interlaced. The mitotic figures and necrosis among various level of differentiations showed significant differences. Importantly, the focal bone and cartilage tissue and extramedullary hematopoiesis were not seen in the similar reports. ${ }^{[2-4]}$

\subsection{Immunohistochemistry and Ultrastructural Fea- tures}

Hepatocellular carcinoma is positive for epithelial markers and AFP, while rhabdomyosarcoma is positive for myogenic markers. The composition complexity of this case is rare. Besides hepatocellular carcinoma and rhabdomyosarcoma, there are also undifferentiated sarcoma and fibrosarcoma components, which have been confirmed by immunohistochemical labeling and ultrastructural observations. ${ }^{[5-7]} \mathrm{Im}-$ portantly, the rhabdomyosarcoma part is foci positive for SDHB and CD117, which has not been observed in previous reports. ${ }^{[2-4]}$

\subsection{Diagnosis and Differential Diagnosis}

The complex tissue structure, diverse cell morphology and various immune expressions in this disease suggest that it needs to be distinguished from the following lesions.

(1) Liver sarcomatoid carcinoma. Most recurrences of this disease occur after repeated radiotherapy and chemother- 
apy. The observations under microscope show mostly secondary reactive fusiform and/or multinucleated giant cells, osteoclast-like giant cells, and/or metaplastic bone or cartilage, and even components such as skeletal muscle. ${ }^{[3,8]}$ As there are only reactive and/or metabolic components, careful observation should be taken combined with the patient medical history.

(2) Hepatoblastoma. This is more common in neonates than it is in adults, and AFP is often elevated. In the background of immature hepatocytes and undifferentiated mesenchymal components and / or bone or cartilage tissue, extrafocal hematopoiesis and typical cholangiolar can be seen under the microscope. ${ }^{[9]}$

(3) Undifferentiated (embryonic) sarcoma, also known as malignant mesenchymal tumor. This is common in children. Microscopic observation shows mixed spindle cells and giant cells constitute the tumor which is sarcoma-like in most cases. Hyperplasia or degeneration of bile duct-like structures are scattered around the most tumors. Ultrastructural observation and immunohistochemical markers show that most cells were undifferentiated mesenchymal cells, fibroblasts, and myofibroblasts. ${ }^{[10]}$ It also shows smooth muscle and skeletal muscle differentiation, but with rare epithelial cell differentiation. It is worth noting that sometimes there are limited cancer tissues in liver cancer sarcoma, suggest-

\section{REFERENCES}

[1] Bosman FT, Carneiro F, Hruban RH, et al. WHO Classification of Tumours of the Digestive System. Lyon:IARC Press, 2010: 249.

[2] Kubosawa $\mathrm{H}$, Ishige $\mathrm{H}$, Kondo $\mathrm{Y}$, et al. Hepatocellular carcinoma with rhabdomyoblastic differentiation. Cancer. 1988; 62(4): 781-786. http://doi.org/10.1002/1097-0142(19880815) 6 $2: 4<781$ : : aid-cncr2820620423>3.0.co;2-t

[3] Akasofu O, Kawahara E, Kaji K, et al. Sarcomatoid hepatocellular carcinoma showing rhabdomyoblastic differentiation in the adult cirrhotic liver. Virchows Arch. 1999; 434(6): 511-515. PMid:10394885. http://doi.org/10.1007/s004280050376

[4] Goldman RL, Friedman NB. Rhabdomyosarcohepatoma in an adult and embryonal hepatoma in a child. Am J Clin Pathol. 1969; 51: 137143. PMid:4303969. http://doi.org/10.1093/ajcp/51.1.13 7

[5] Folpe AL. MyoD1 and myogenin expression in human Neoplasia: a review and update. Adv Anat Pathol. 2002; 9(3): 198-203. PMid:11981115. http://doi.org/10.1097/00125480-20020 5000-00003

[6] Kumar S, Perlman E, Harris CA, et al. Myogenin is a specific marker for rhabdomyosarcoma: an immunoistochemical study in paraffin-embedded tissues. Mod Pathol. 2000; 13(9): 988-993. PMid:11007039. https://doi.org/10.1038/modpathol. 3880 179 ing more materials and sections need to be taken, and the components of the cancer should be confirmed by immunohistochemistry. There should be at least carcinoma in situ and severe dysplasia epithelial tissue in the periphery of the sarcoma tissue; otherwise it must be carefully distinguished from real sarcomas such as leiomyosarcoma and malignant schwannoma, etc. ${ }^{[11]}$

\subsection{Treat strategies and Prognosis}

In the early stage of the disease, only discomforts in the upper abdomen can be noted. Imaging examinations suggest liver-occupying lesions, from which liver cancer can be prior to be taken into consideration mostly. The treatment is mostly palliative surgery, supplemented by radiotherapy and chemotherapy. However, the outcome is poor and the survival period is only 14 days to 3 months. ${ }^{[2-4]}$ In this reported case, there is a single giant nodule in the left lobe of the liver, which is completely resected without following radiotherapy and chemotherapy. There is no recurrence and metastasis after 12 months of following up. Future follow-up and more data are warranted to determine whether HCSR prognosis is correlated to the number of lesions, size, location, presence or absence of necrosis and molecular phenotype needs collected.

\section{CONFlicts of InTEREST Disclosure}

We declare that we have no conflict interests.
[7] Morotti RA, Nicol KK, Parham DM, et al. An immunohistochemical algorithm to facilitate diagnosis and subtyping of rhabdomyosarcoma: the Children's Oncology Group experience. Am J Surg Pathol. 2006; 30(8): 962-968. PMid:16861966. https : //doi .org/10.1097/00 000478-200608000-00005

[8] Kakizoe S, Kojiro M, Nakashima T. Hepatocellular carcinoma with sarcomatous change. Clinicopathlogic and immunohistochemical studies of 14 autopsy cases. Cancer. 1987; 59: 405-430. https://doi.org/10.1002/1097-0142(198701 15) $59: 2<310::$ AID-CNCR2820590224>3.0.CO; $2-\mathrm{S}$

[9] Zimmermann A. Hepatoblastoma with cholangioblatic features (cholangioblastic hepatoblastoma) and other liver tumors with bimodal differentiation in young patients. Med Pediatr Oncol. 2002; 39: 487-491. PMid:12228905. https ://doi.org/10.1002/mpo. 10173

[10] Nishio J, Iwasaki H, Sakashita N, et al. (2003). Undifferentiated(embryonal) sarcoma of the liver in middle-aged adults: smooth muscle differentiation determined by immunohistochemistry and electron microscopy. Hum Pathol. 2003; 34: 246-252. PMid:12673559. https://doi.org/10.1053/hupa.2003.44

[11] Qiu SS, Deng X, Li DQ, et al. Clinicopathologic features of the liver carcinosarcoma. Chongqing Medicine. 2012; 41(36): 3859-3861. 